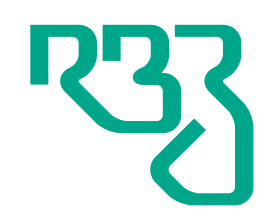

\section{Revista}

Brasileira de

Zootecnia

Brazilian Journal of Animal Science

ISSN 1806-9290

www.rbz.org.br

\title{
Effect of different sources of selenium on performance and characteristics of immune system of broiler chickens
}

\author{
Roozbeh Shabani $^{1}$ (iD) , Jafar Fakhraei ${ }^{{ }^{*}}$ (iD), Hossein Mansoori Yarahmadi ${ }^{1}$ iD, \\ Alireza Seidavi $^{2}$ iD \\ ${ }^{1}$ Department of Animal Science, Arak Branch, Islamic Azad University, Arak, Iran. \\ ${ }^{2}$ Department of Animal Science, Rasht Branch, Islamic Azad University, Rasht, Iran.
}

\author{
*Corresponding author: \\ j-fakhraei@iau-arak.ac.ir \\ Received: October 26, 2018 \\ Accepted: January 9, 2019 \\ How to cite: Shabani, R.; Fakhraei, J.; Yarahmadi, \\ H. M. and Seidavi, A. 2019. Effect of different \\ sources of selenium on performance and \\ characteristics of immune system of broiler \\ chickens. Revista Brasileira de Zootecnia \\ 48:e20180256. \\ https://doi.org/10.1590/rbz4820180256 \\ Copyright: This is an open access article \\ distributed under the terms of the \\ Creative Commons Attribution License \\ (http://creativecommons.org/licenses/by/4.0/), \\ which permits unrestricted use, distribution, \\ and reproduction in any medium, provided the \\ original work is properly cited.
}

\begin{abstract}
An experiment was conducted based on a completely randomized design with 500 Ross 308 broiler chickens to investigate the effect of three different sources of selenium on performance and characteristics of immune system. Chickens were arranged in 10 treatments and five repetitions (10 chickens for each repetition). Ten treatments of experimental diet were considered in the study, including a basal diet (control); 0.5, 0.8, and $1.2 \mathrm{mg}$ nano-selenium + basal diet (three treatments); 0.5, 0.8, $1.2 \mathrm{mg}$ selenomethionine + basal diet; and 65,80 , and $100 \mathrm{mg}$ vitamin $\mathrm{E}+$ selenium + basal diet. Findings suggested that adding selenomethionine $(1.2 \mathrm{mg})$ to the basal diet resulted in a significant effect on feed conversion ratio and weight of broilers. In fact, weight and bursa of Fabricius were significantly under influence of the diets containing nano-selenium. Moreover, a significant difference was observed in the antibodies produced against Newcastle and influenza as well as the total immunoglobin and IgG produced against sheep red blood cell at two stages in the group treated with nanoselenium. Finally, results indicated that nano-selenium can better improve performance and immune system of broilers compared with diets containing selenomethionine and vitamin E.
\end{abstract}

\section{Introduction}

Optimized production and sustainable health in poultry require providing sufficient necessary nutrients which are available to the body. Most feeds commonly provided for farm animals are deficient in some nutrients and, therefore, need supplements (Umesh et al., 2004).

While required only at minute doses, selenium is an essential feature of feed supplements having a special position among the natural antioxidants available in feed and is an inseparable component of selenoproteins involved in regulating physiologic processes of the body of animals (Zhang et al., 2017). As a component of intracellular glutathione peroxidase enzyme, selenium provides the first and second defense layer of the body against oxidative agents. Glutathione peroxidase is a crucial enzyme for reducing oxidative reactions in the internal structures of the cells as free radicals are continuously produced during physiological activities, and their production is even increased under stress conditions. The main sources of free radical production in cells are electron transport chain in mitochondria, metabolism enzymes, and immune systems.

Immune system cells produce more free radicals to kill pathogenic agents (Perić et al., 2009). Selenium prevents peroxidation of arachidonic acid and protects immune system cells and tissues from the damage caused by free radicals (Ahmad et al., 2014; Canogullari et al., 2010). It also plays an important 
role in the process of peroxidase glutathione production aiming at improving the immune system, stimulating production of white blood cells and activity of the thymus (Invernizzi et al., 2013).

Selenium supplement is usually applied in mineral or organic forms in poultry diets. Although organic selenium has a higher potential for uptake, there are some reports on more favorable performance of mineral selenium with vitamin E on the performance of poultry (Perez et al., 2010). While some researchers believe that applying mineral or organic selenium has no effect on the immune system of chickens (Biswas et al., 2006), numerous studies have shown that a new source called nano-selenium has a more favorable performance in poultry diets (Shirsat et al., 2016).

Since the uptake of each source of selenium supplement varies and considering the fact that previous studies investigated the effects of organic, mineral, and nano-selenium separately, the present study aimed at evaluating the effects of various selenium supplements on the performance and immune systems of broiler chickens.

\section{Material and Methods}

The experiment was carried out in accordance with local Animal Care and Use Committee (case number 2018/96-10 A). The trial was performed in Lahijan, Iran (37.2071 $\left.{ }^{\circ} \mathrm{N}, 50.0034^{\circ} \mathrm{E}\right)$. Five hundred male Ross 308 broiler chickens were fed three different sources of selenium (nano-selenium, selenomethionine, and vitamin E + selenium) at three levels in a completely randomized design with 10 treatments and five repetitions, each containing 10 chickens. Experimental groups included a basal diet (control), $0.5 \mathrm{mg}$ nano-selenium + basal diet, $0.8 \mathrm{mg}$ nano-selenium + basal diet, $1.2 \mathrm{mg}$ nanoselenium + basal diet, $0.5 \mathrm{mg}$ selenomethionine + basal diet, $0.8 \mathrm{mg}$ selenomethionine + basal diet, $1.2 \mathrm{mg}$ selenomethionine + basal diet, $65 \mathrm{mg}$ vitamin $\mathrm{E}+$ selenium + basal diet, $80 \mathrm{mg}$ vitamin $\mathrm{E}+$ selenium + basal diet, and $100 \mathrm{mg}$ vitamin $\mathrm{E}+$ selenium + basal diet. All treatment groups were fed the same basal diet based on the nutritional requirements recommended for Ross 308 chickens (Table 1). Nutrient composition of concentrated feeds was determined according to AOAC (2003). Allocation of ingredients of the diets was computed using UFFDA software.

Growth conditions for all chickens were the same during the experiment, and chickens had free access to feed. Feeds in each repetition were weighed before intake, and by weighing the remained feed by the end of each week, the total volume of the feeds consumed in each group during the experimental period were calculated. In addition, chickens were weighed weekly, and the increased weight as well as feed conversion ratio were recorded at the end of the experiment.

To investigate the effects of experimental treatments on the weights of lymphoid organs, one chicken from each repetition was randomly selected and euthanized at the end of the experiment (day 42), and three lymphoid organs, namely, the thymus, spleen, and bursa of Fabricius, were removed and weighed using a digital scale ( \pm 0.01 error of measurement) to determine their ratio to body weight.

To determine antibody titers that neutralize Newcastle and influenza viruses, Newcastle and influenza inocula were injected into the 8- and 18-day-old chickens, respectively. The first and second blood samples were collected on days 10 and 20 after inoculation. One chicken from each repetition was randomly selected and $2 \mathrm{~mL}$ blood samples were collected from the wing vein. The samples were sent to the laboratory where they were centrifuged at $3000 \mathrm{rpm}$ for $15 \mathrm{~min}$ to extract serum (Cai et al., 2012).

To evaluate humoral immune system, four chickens in each group were selected and $0.2 \mathrm{~mL}$ sheep red blood cell (SRBC) at 5\% suspension, washed in sterilized phosphate buffer, was injected in their pectoral muscles. This was followed by collecting $2 \mathrm{~mL}$ blood samples from the wing veins of the same chickens, which were stained on the feather for recognition, seven days after injection, i.e., on days 28 and 35. The blood samples were kept at normal laboratory temperature for $6 \mathrm{~h}$, so that the serum was separated from the clot. The obtained serum was then centrifuged at $4000 \mathrm{rpm}$ for $15 \mathrm{~min}$. To determine the produced antibody titer against SRBC and IgG, hemagglutination microtitration method was used (Peterson et al., 1999).

R. Bras. Zootec., 48:e20180256, 2019 
Table 1 - Ingredients of the experimental diets

\begin{tabular}{lccc}
\hline Ingredient (g/kg) & $\begin{array}{c}\text { Starter } \\
\text { (1-10 days old) }\end{array}$ & $\begin{array}{c}\text { Grower } \\
\text { (11-28 days old) }\end{array}$ & $\begin{array}{c}\text { Finisher } \\
\text { (29-42 days old) }\end{array}$ \\
\hline Corn & 545 & 585 & 627 \\
Soybean & 375 & 335 & 295 \\
Sunflower oil & 40 & 40 & 40 \\
Calcium carbonate & 12 & 12 & 11 \\
Dicalcium phosphate & 16 & 15 & 15 \\
Salt & 2.3 & 2.6 & 2.5 \\
Mineral premix ${ }^{1}$ & 3 & 3 & 3 \\
Vitamin premix & 3 & 3 & 3 \\
Sodium bicarbonate & 1.2 & 1.4 & 1 \\
DL-methionine & 1.8 & 2.1 & 1.5 \\
DL-lysine & 0.7 & 0.9 & 1 \\
Chemical analysis & & & \\
Metabolizable energy $(\mathrm{kcal} / \mathrm{kg})$ & 3010 & 3050 & 3100 \\
Crude protein $(\mathrm{g} / \mathrm{kg})$ & 210.4 & 196 & 188.8 \\
Lysine (g/kg) & 12.7 & 11 & 9.7 \\
Methionine + cysteine $(\mathrm{g} / \mathrm{kg})$ & 9.4 & 8.4 & 7.6 \\
Methionine $(\mathrm{g} / \mathrm{kg})$ & 4.7 & 4.2 & 3.6 \\
Arginine $(\mathrm{g} / \mathrm{kg})$ & 13.1 & 11.4 & 10.2 \\
Tryptophan $(\mathrm{g} / \mathrm{kg})$ & 2 & 1.8 & 1.6 \\
Ca (g/kg) & 10.5 & 9.0 & 8.5 \\
Available phosphorus $(\mathrm{g} / \mathrm{kg})$ & 5 & 4.5 & 4.2 \\
Na (g/kg) & 210.4 & 196 & 181.8 \\
Cl (g/kg) & 1.7 & 1.7 & 1.6 \\
\hline
\end{tabular}

${ }^{1}$ Mineral mixture per kg of diet: Mn, 100 mg; Zn, 85 mg; Fe, 50 mg; Cu, 10 mg; Se, 0.2 mg; I, 1 mg.

${ }^{2}$ Vitamin premix per kg of diet: vitamin A, $9000 \mathrm{IU}$; vitamin $\mathrm{D}_{3}, 2000 \mathrm{IU}$; vitamin E, $18 \mathrm{IU}$; vitamin $\mathrm{K}_{3}, 2 \mathrm{mg}$; vitamin $\mathrm{B}_{6}, 3 \mathrm{mg}$; vitamin $\mathrm{B}_{12}, 0.015 \mathrm{mg}$; thiamine, $1.8 \mathrm{mg}$; riboflavin, $6.6 \mathrm{mg}$; pantothenate, $10 \mathrm{mg}$; nicotinic acid, $30 \mathrm{mg}$; folic acid, $1 \mathrm{mg}$; vitamin H2, $0.1 \mathrm{mg}$; choline chloride, $400 \mathrm{mg}$.

The data obtained from the completely randomized design experiment were subjected to statistical analysis using SAS (Statistical Analysis System, version 9.1) and general linear models (GLM). Means were compared using Duncan's test at $\mathrm{P} \leq 0.05$. The statistical model used was as follows:

$$
\mathrm{Y}_{\mathrm{ij}}=\mu+\mathrm{A}_{\mathrm{i}}+\mathrm{e}_{\mathrm{ij}}
$$

in which $Y_{i j}$ is the observations of traits, $\mu$ is the overall mean, $A_{i}$ is the treatment effect, and $e_{i j}$ is the experimental error.

\section{Results}

Increases in the weights of chickens in treatments with $65 \mathrm{mg}$ vitamin $\mathrm{E}+$ selenium + basal diet and $80 \mathrm{mg}$ vitamin $\mathrm{E}+$ selenium + basal diet, which contained selenium and vitamin E supplements, were significantly different compared with those in control group ( $\mathrm{P} \leq 0.05)$ (Table 2). However, there was a difference between $1.2 \mathrm{mg}$ selenomethionine and control group ( $\mathrm{P} \leq 0.05$; Table 2). While the difference between increased weight of the group treated with nano-selenium and the control group was not significant, it showed more improvement compared with the group receiving vitamin E + selenium treatment.

Feed intake in treatment $65 \mathrm{mg}$ vitamin $\mathrm{E}+$ selenium + basal diet significantly reduced in comparison with that of the control and treatments $0.5 \mathrm{mg}$ nano-selenium + basal diet, $0.8 \mathrm{mg}$ nano-selenium + basal diet, $1.2 \mathrm{mg}$ nano-selenium + basal diet and $1.2 \mathrm{mg}$ selenomethionine + basal diet $(\mathrm{P} \leq 0.05)$ (Table 2). Although the highest feed intake was recorded in the group treated with nano-selenium, it was not significantly different from the control chickens ( $\mathrm{P} \leq 0.05)$. 
Moreover, feed conversion ratio (FCR) in treatment $1.2 \mathrm{mg}$ selenomethionine + basal diet showed a statistically significant difference compared with the control $(\mathrm{P} \leq 0.05)$ (Table 2). In fact, the lowest FCR in the experimental groups were observed in birds treated with selenomethionine.

No significant difference was observed between the control and experimental groups in relation to weight and percentage of thymus and spleens ( $\mathrm{P} \leq 0.05)$ (Table 3). Numerically, the highest weight and thymus percentages were recorded in treatment $0.8 \mathrm{mg}$ nano-selenium + basal diet, which showed significant difference compared with treatment $0.5 \mathrm{mg}$ nano-selenium + basal diet $(\mathrm{P} \leq 0.05)$. In addition, the weight and percentage of bursa of Fabricius in broilers treated with nano-selenium showed a significant difference compared with the control $(\mathrm{P} \leq 0.05)$.

Table 2 - Effects of different sources of selenium on body weight gain (BWG), feed intake (FI), and feed conversion ratio (FCR)

\begin{tabular}{lccc}
\hline & \multicolumn{3}{c}{1 to 42 days } \\
\cline { 2 - 4 } Treatment & BWG (g) & FI (g/hen/period) & FCR \\
\cline { 2 - 4 } Basal diet (control) & $62.6244 \pm 0.451 \mathrm{bc}$ & $115.4856 \pm 0.484 \mathrm{ab}$ & $1.69700 \pm 0.0142 \mathrm{dc}$ \\
Basal diet + 0.5 mg nano-selenium & $62.8998 \pm 0.451 \mathrm{bc}$ & $115.3640 \pm 0.484 \mathrm{ab}$ & $1.69640 \pm 0.0142 \mathrm{dc}$ \\
Basal diet + 0.8 mg nano-selenium & $62.6282 \pm 0.451 \mathrm{bc}$ & $115.5912 \pm 0.484 \mathrm{ab}$ & $1.70980 \pm 0.0142 \mathrm{abc}$ \\
Basal diet + $1.2 \mathrm{mg}$ nano-selenium & $63.7782 \pm 0.451 \mathrm{ab}$ & $115.8714 \pm 0.484 \mathrm{a}$ & $1.68060 \pm 0.0142 \mathrm{dc}$ \\
Basal diet + 0.5 mg selenomethionine & $63.6926 \pm 0.541 \mathrm{ab}$ & $114.1644 \pm 0.484 \mathrm{bc}$ & $1.65780 \pm 0.0142 \mathrm{de}$ \\
Basal diet + 0.8 mg selenomethionine & $62.1060 \pm 0.541 \mathrm{bc}$ & $114.7288 \pm 0.484 \mathrm{abc}$ & $1.70340 \pm 0.0142 \mathrm{bc}$ \\
Basal diet + $1.2 \mathrm{mg}$ selenomethionine & $65.102 \pm 0.4514 \mathrm{a}$ & $115.3232 \pm 0.484 \mathrm{ab}$ & $1.63080 \pm 0.0142 \mathrm{e}$ \\
Basal diet + $65 \mathrm{mg}$ (vit. E + selenium) & $60.1358 \pm 0.541 \mathrm{~d}$ & $113.6532 \pm 0.484 \mathrm{c}$ & $1.74380 \pm 0.0142 \mathrm{ab}$ \\
Basal diet + $80 \mathrm{mg}$ (vit. E + selenium) & $60.4070 \pm 0.541 \mathrm{~d}$ & $114.4578 \pm 0.484 \mathrm{abc}$ & $1.75220 \pm 0.0142 \mathrm{a}$ \\
Basal diet + $100 \mathrm{mg}$ (vit. E + selenium) & $61.3112 \pm 0.541 \mathrm{dc}$ & $114.0708 \pm 0.484 \mathrm{bc}$ & $1.72220 \pm 0.0142 \mathrm{abc}$ \\
SEM & 0.5412 & 0.4844 & 0.0142 \\
\hline
\end{tabular}

SEM - standard error of the means.

The means within the same column with at least one common letter do not have significant difference $(\mathrm{P}>0.05)$.

Table 3 - Effects of different sources of selenium on weight and percentage of lymphoid organs

\begin{tabular}{lcccccc}
\hline Treatment & Thymus (g) & Thymus (\%) & Spleen (g) & Spleen (\%) & Bursa (g) & Bursa (\%) \\
\hline Basal diet (control) & $5.240 \pm$ & $0.27880 \pm$ & $2.9720 \pm$ & $0.15860 \pm$ & $2.1880 \pm$ & $0.11640 \pm$ \\
& $0.7694 \mathrm{ab}$ & $0.04353 \mathrm{ab}$ & $0.35161 \mathrm{a}$ & $0.01878 \mathrm{a}$ & $0.51005 \mathrm{~d}$ & $0.02949 \mathrm{~b}$ \\
Basal diet + 0.5 mg & $3.652 \pm$ & $0.18600 \pm$ & $2.7180 \pm$ & $0.13760 \pm$ & $2.5600 \pm$ & $0.21760 \pm$ \\
nano-selenium & $0.7694 \mathrm{~b}$ & $0.04353 \mathrm{~b}$ & $0.35161 \mathrm{a}$ & $0.01878 \mathrm{a}$ & $0.51005 \mathrm{a}$ & $0.02949 \mathrm{a}$ \\
Basal diet + 0.8 mg & $6.700 \pm$ & $0.34380 \pm$ & $2.1280 \pm$ & $0.10700 \pm$ & $3.9000 \pm$ & $0.19220 \pm$ \\
nano-selenium & $0.7694 \mathrm{a}$ & $0.04353 \mathrm{a}$ & $0.35161 \mathrm{a}$ & $0.01878 \mathrm{a}$ & $0.51005 \mathrm{abc}$ & $0.02949 \mathrm{ab}$ \\
Basal diet + $1.2 \mathrm{mg}$ & $4.400 \pm$ & $0.24040 \pm$ & $2.3280 \pm$ & $0.12280 \pm$ & $4.5020 \pm$ & $0.23600 \pm$ \\
nano-selenium & $0.7694 \mathrm{ab}$ & $0.04353 \mathrm{ab}$ & $0.35161 \mathrm{a}$ & $0.01878 \mathrm{a}$ & $0.51005 \mathrm{ab}$ & $0.02949 \mathrm{a}$ \\
Basal diet + 0.5 mg & $5.780 \pm$ & $0.28000 \pm$ & $2.9280 \pm$ & $0.14100 \pm$ & $2.8380 \pm$ & $0.16380 \pm$ \\
selenomethionine & $0.7694 \mathrm{ab}$ & $0.04353 \mathrm{ab}$ & $0.35161 \mathrm{a}$ & $0.01878 \mathrm{a}$ & $0.51005 \mathrm{bcd}$ & $0.02949 \mathrm{ab}$ \\
Basal diet + 0.8 mg & $5.660 \pm$ & $0.28000 \pm$ & $2.8740 \pm$ & $0.14200 \pm$ & $3.5200 \pm$ & $0.18440 \pm$ \\
selenomethionine & $0.7694 \mathrm{ab}$ & $0.04353 \mathrm{ab}$ & $0.35161 \mathrm{a}$ & $0.01878 \mathrm{a}$ & $0.51005 \mathrm{abcd}$ & $0.02949 \mathrm{ab}$ \\
Basal diet + $1.2 \mathrm{mg}$ & $5.020 \pm$ & $0.25780 \pm$ & $2.1240 \pm$ & $0.10800 \pm$ & $3.4800 \pm$ & $0.18520 \pm$ \\
selenomethionine & $0.7694 \mathrm{ab}$ & $0.04353 \mathrm{ab}$ & $0.35161 \mathrm{a}$ & $0.01878 \mathrm{a}$ & $0.51005 \mathrm{abcd}$ & $0.02949 \mathrm{ab}$ \\
Basal diet + 65 mg & $4.120 \pm$ & $0.23700 \pm$ & $2.5460 \pm$ & $0.14580 \pm$ & $3.1880 \pm$ & $0.16400 \pm$ \\
(vit. E + selenium) & $0.7694 \mathrm{~b}$ & $0.04353 \mathrm{ab}$ & $0.35161 \mathrm{a}$ & $0.01878 \mathrm{a}$ & $0.51005 \mathrm{abcd}$ & $0.02949 \mathrm{ab}$ \\
Basal diet + 80 mg & $5.900 \pm$ & $0.30620 \pm$ & $2.6000 \pm$ & $0.13500 \pm$ & $2.5000 \pm$ & $0.17860 \pm$ \\
(vit. E + selenium) & $0.7694 \mathrm{ab}$ & $0.04353 \mathrm{ab}$ & $0.35161 \mathrm{a}$ & $0.01878 \mathrm{a}$ & $0.51005 \mathrm{abcd}$ & $0.02949 \mathrm{ab}$ \\
Basal diet + $100 \mathrm{mg}$ & $5.740 \pm$ & $0.30760 \pm$ & $2.6000 \pm$ & $0.13920 \pm$ & $2.6620 \pm$ & $0.14120 \pm$ \\
(vit. E + selenium) & $0.7694 \mathrm{ab}$ & $0.04353 \mathrm{ab}$ & $0.35161 \mathrm{a}$ & $0.01878 \mathrm{a}$ & $0.51005 \mathrm{~cd}$ & $0.02949 \mathrm{ab}$ \\
SEM & 0.7694 & 0.0435 & 0.35161 & 0.01878 & 0.5100 & 0.0294 \\
\hline
\end{tabular}

SEM - standard error of the means.

Means within the same column with at least one common letter do not have significant difference $(\mathrm{P}>0.05)$. 
In the first and second sampling times, Newcastle titer in the nano-selenium group showed a significant difference between the control and the other experimental groups $(\mathrm{P} \leq 0.05)$ (Table 4). A significant difference was also observed between the selenomethionine and control group $(\mathrm{P} \leq 0.05)$. However, no significant difference was found between selenomethionine and vitamin $\mathrm{E}+$ selenium group $(\mathrm{P} \leq 0.05)$. In the first sampling time, the differences between influenza titer in the nano-selenium and control as well as selenomethionine and vitamin $\mathrm{E}+$ selenium groups were significant $(\mathrm{P} \leq 0.05)$. In addition, nano-selenium and selenomethionine showed a significant difference in influenza titer with the control in the second sampling time $(\mathrm{P} \leq 0.05)$.

Total immunoglobin titer at two stages and the IgG at stage one for the experimental group treated with nano-selenium were significantly different from those of the control and other experimental groups $(\mathrm{P} \leq 0.05)$ (Table 5). The IgG titer at the second stage showed significant difference $(\mathrm{P} \leq 0.05)$ only with the control group.

Table 4 - Effects of different sources of selenium on immune responses of broiler chickens after vaccination

\begin{tabular}{lcccc}
\hline Treatment & ATAN1 $\left(\log _{2}\right)$ & ATAN2 $\left(\log _{2}\right)$ & ATAA1 $\left(\log _{10}\right)$ & ATAA2 $\left(\log _{10}\right)$ \\
\hline Basal diet (control) & $6.0000 \pm 0.2449 \mathrm{~d}$ & $7.6000 \pm 0.2863 \mathrm{c}$ & $6.000 \pm 0.24083 \mathrm{e}$ & $6.8000 \pm 0.29898 \mathrm{~d}$ \\
Basal diet + 0.5 mg nano-selenium & $9.2000 \pm 0.2449 \mathrm{a}$ & $9.0000 \pm 0.2863 \mathrm{a}$ & $8.0000 \pm 0.24083 \mathrm{~b}$ & $8.4000 \pm 0.29898 \mathrm{a}$ \\
Basal diet + 0.8 mg nano-selenium & $8.4000 \pm 0.2449 \mathrm{~b}$ & $8.8000 \pm 0.2863 \mathrm{ab}$ & $7.8000 \pm 0.24083 \mathrm{~b}$ & $8.0000 \pm 0.29898 \mathrm{ab}$ \\
Basal diet + $1.2 \mathrm{mg}$ nano-selenium & $8.2000 \pm 0.2449 \mathrm{~b}$ & $8.6000 \pm 0.2863 \mathrm{ab}$ & $8.8000 \pm 0.24083 \mathrm{a}$ & $7.40000 \pm 0.29898 \mathrm{bc}$ \\
Basal diet + 0.5 mg selenomethionine & $7.0000 \pm 0.2449 \mathrm{c}$ & $8.0000 \pm 0.2863 \mathrm{bc}$ & $6.4000 \pm 0.24083 \mathrm{de}$ & $7.6000 \pm 0.2898 \mathrm{abc}$ \\
Basal diet + 0.8 mg selenomethionine & $7.4000 \pm 0.2449 \mathrm{c}$ & $8.0000 \pm 0.2863 \mathrm{bc}$ & $6.4000 \pm 0.24083 \mathrm{de}$ & $7.6000 \pm 0.29898 \mathrm{abc}$ \\
Basal diet + 1.2 mg selenomethionine & $7.0000 \pm 0.2449 \mathrm{c}$ & $8.6000 \pm 0.2863 \mathrm{ab}$ & $7.4000 \pm 0.24083 \mathrm{bc}$ & $8.2000 \pm 0.29898 \mathrm{ab}$ \\
Basal diet + 65 mg (vit. E + selenium) & $6.2000 \pm 0.2449 \mathrm{~d}$ & $7.6000 \pm 0.2863 \mathrm{c}$ & $6.2000 \pm 0.24083 \mathrm{de}$ & $8.2000 \pm 0.29898 \mathrm{ab}$ \\
Basal diet + 80 mg (vit. E + selenium) & $7.4000 \pm 0.2449 \mathrm{c}$ & $8.2000 \pm 0.2863 \mathrm{abc}$ & $6.8000 \pm 0.24083 \mathrm{dc}$ & $7.8000 \pm 0.29898 \mathrm{ab}$ \\
Basal diet + 100 mg (vit. E + selenium) & $7.0000 \pm 0.2449 \mathrm{c}$ & $8.0000 \pm 0.2863 \mathrm{bc}$ & $6.2000 \pm 0.24083 \mathrm{de}$ & $6.2000 \pm 0.29898 \mathrm{~d}$ \\
SEM & 0.2449 & 0.2863 & 0.2408 & 0.2898 \\
\hline
\end{tabular}

ATAN1 - antibody titre against Newcastle at first time; ATAN2 - antibody titre against Newcastle at second time; ATAA1 - antibody titre against Influenza at first time; ATAA2 - antibody titre against Influenza at second time. SEM - standard error of the means. Means within the same column with at least one common letter do not have significant difference $(\mathrm{P}>0.05)$.

Table 5 - Effects of different sources of selenium on immune responses of broiler chickens after sheep red blood cell injection

\begin{tabular}{lcccc}
\hline Treatment & Total Ig $1\left(\log _{10}\right)$ & Total Ig $2\left(\log _{10}\right)$ & $\operatorname{IgG} 1\left(\log _{10}\right)$ & IgG $2\left(\log _{10}\right)$ \\
\hline Basal diet (control) & $1.8000 \pm 0.27202 \mathrm{~cd}$ & $1.2000 \pm 0.2645 \mathrm{~d}$ & $5.6000 \pm 0.4404 \mathrm{c}$ & $4.8000 \pm 0.2645 \mathrm{c}$ \\
Basal diet + 0.5 mg nano-selenium & $2.2000 \pm 0.27202 \mathrm{bc}$ & $2.6000 \pm 0.2645 \mathrm{~b}$ & $7.4000 \pm 0.4404 \mathrm{~b}$ & $7.4000 \pm 0.2645 \mathrm{ab}$ \\
Basal diet + 0.8 mg nano-selenium & $2.8000 \pm 0.27202 \mathrm{~b}$ & $4.0000 \pm 0.2645 \mathrm{a}$ & $8.8000 \pm 0.4404 \mathrm{a}$ & $8.4000 \pm 0.2645 \mathrm{a}$ \\
Basal diet + $1.2 \mathrm{mg}$ nano-selenium & $4.0000 \pm 0.27202 \mathrm{a}$ & $2.4000 \pm 0.2645 \mathrm{bc}$ & $7.4000 \pm 0.4404 \mathrm{~b}$ & $7.4000 \pm 0.2645 \mathrm{ab}$ \\
Basal diet + 0.5 mg met-selenium & $1.6000 \pm 0.27202 \mathrm{~cd}$ & $2.0000 \pm 0.2645 \mathrm{bcd}$ & $5.2000 \pm 0.4404 \mathrm{c}$ & $5.0000 \pm 0.2645 \mathrm{c}$ \\
Basal diet + 0.8 mg met-selenium & $1.6000 \pm 0.27202 \mathrm{~cd}$ & $1.2000 \pm 0.2645 \mathrm{~d}$ & $6.0000 \pm 0.4404 \mathrm{c}$ & $6.4000 \pm 0.2645 \mathrm{abc}$ \\
Basal diet + $1.2 \mathrm{mg}$ met-selenium & $1.2000 \pm 0.27202 \mathrm{~d}$ & $1.2000 \pm 0.2645 \mathrm{~d}$ & $5.8000 \pm 0.4404 \mathrm{c}$ & $5.0000 \pm 0.2645 \mathrm{c}$ \\
Basal diet + $65 \mathrm{mg}$ (vit. E + selenium) & $1.4000 \pm 0.27202 \mathrm{~cd}$ & $1.6000 \pm 0.2645 \mathrm{~d}$ & $6.0000 \pm 0.4404 \mathrm{c}$ & $7.0000 \pm 0.2645 \mathrm{abc}$ \\
Basal diet + $80 \mathrm{mg}$ (vit. E + selenium) & $1.2000 \pm 0.27202 \mathrm{~d}$ & $1.2000 \pm 0.2645 \mathrm{~d}$ & $5.8000 \pm 0.4404 \mathrm{c}$ & $6.0000 \pm 0.2645 \mathrm{bc}$ \\
Basal diet + $100 \mathrm{mg}$ (vit. E + selenium) & $1.6000 \pm 0.27202 \mathrm{~cd}$ & $1.6000 \pm 0.2645 \mathrm{~d}$ & $6.0000 \pm 0.4404 \mathrm{c}$ & $5.2000 \pm 0.2645 \mathrm{bc}$ \\
SEM & 0.2720 & 0.4404 & 0.2645 & 0.6942 \\
\hline
\end{tabular}

SEM - standard error of the means.

Means within the same column with at least one common letter do not have significant difference $(P>0.05)$. 


\section{Discussion}

As the findings revealed, weights in nano-selenium and selenomethionine groups generally improved, and the increase in weight and FCR in selenomethionine group was statistically significant, which is consistent with the findings of Spears et al. (2003). Better growth in the group treated with organic selenium can be attributed to the low growth of feathers in nano-selenium and $\mathrm{E}+$ selenium groups (Edens et al., 2001). There are studies reporting increased feather growth in broiler chickens fed organic selenium (selenomethionine). The growth in feathers may be because amino acids containing selenium (selenomethionine and selenocysteine) participate in the production of keratin needed for feather production and growth (Choct et al., 2004). Besides, one of the reasons for the more pronounced effect of organic selenium is the bioavailability of selenium in organic resources (Rama Rao et al., 2013). Surai (2002) argued that the uptake difference between organic and nonorganic selenium can be explained on the ground that the uptake in organic selenium (e.g., selenomethionine) is active and results in the production of proteins in body organs. Naylor et al. (2000) reported improved FCR by supplementary organic selenium in poultry feed. Yoon et al. (2007) attributed the improved FCR and weights in poultry treated with selenomethionine to the increased feather production, since degenerate feathering results in the need for more energy to maintain the chickens.

Edens et al. (2000) in their study found that feed intake and weight gain of poultry treated with vitamin $\mathrm{E}$ and selenium were lower compared with the control, which is consistent with the findings of the present study. The study by Basmacioğlu et al. (2009) also suggested that vitamin E and selenium supplements in broiler diet increased feed conversion as it reduced feed intake and weight of broiler chickens. Ryu et al. (2005) and Edens (2000) argued that broiler diets containing vitamin E and selenium are less palatable, and this results in the reduced feed intake and weight.

Weight and bursa of Fabricius percentage in the group treated with nano-selenium were significantly different from those of the control broilers. Some researchers believe that sufficient levels of selenium in the diet through increasing antioxidant activities of GSH-PX enzyme and scavenging most toxic compounds resulted from cellular metabolism (free radicals) improves the immune system; therefore, deficiency in selenium leads to changes in, and damages to, the immune system tissues such as those of bursa of Fabricius, which is the locus for lymphocyte production. This in turn, results in the impairment in the performance and also reduced growth in bursa of Fabricius (Kojouri and Sharifi, 2013). Since the speed of transportation and uptake of nano-selenium particles are more than those of selenium from other sources, the activity of GSH-PX increases, and the performance of lymphoid organs is improved (Sadeghian et al., 2012).

According to the results, antibody titers produced for Newcastle and influenza at both stages were significantly increased in the nano-selenium group compared with the control. While the antibody titer in the selenomethionine group was significantly affected at the second stage, it was more affected in the nano-selenium group, agreeing with the findings of Liao et al. (2012) and Zhou and Wang (2011).

Deficiency in selenium results in the reduced immune response through interference with the activities of neutrophils, macrophages, and leukocytes. This is based on a mechanism in which, under reduced selenium content, glutathione peroxidase reduces while the production of lipid hydroperoxides and peroxides increases. This increases and accumulates toxic compounds in neutrophils and as a result, reduces the immune response (Wen et al., 1998). Moreover, selenium deficiency in the body interferes with the secretion of tumor necrosis factors by macrophages, and this reduces nutrient input into the blood vessels to improve the immune system (Cao et al., 2002). Studies suggest that the oxidant and pro oxidant effects or biologic and toxic capabilities of selenium depend on its chemical configuration. It has also been reported that nano-selenium particles are more efficient in the immune response compared with selenomethionine and vitamin E + selenium (Ahmadi et al., 2018; Zhang et al., 2008), confirming the finding of the present study.

Nano-selenium treatment showed a significant difference in the values of total immunoglobins and IgG produced after injection of SRBC at both stages between the control and the other experimental

R. Bras. Zootec., 48:e20180256, 2019 
groups (Wang et al., 2007; Kumar et al., 2009). The SRBC is a T cell antigen, which means that when SRBC is injected into the body, cooperation of T cells to activate B cells and, therefore, immunoglobin, is vital (Hegazy and Adachi, 2000). The cytokines secreted from lymphocytes of type $2 \mathrm{~T}$ helper cells (Th2 cells) include Interleukin 4, 5, and 13 (IL-4, IL-5, and IL-13, respectively), which are necessary for starting humoral immunity to specialize B cell lymphocytes for production of immunoglobins (Abbas et al. 2015). The more developed the specialization of B cell lymphocytes are, the more immunoglobins are produced (Yang et al., 2000). Pighetti et al. (1998) believed that selenium deficit in feeds reduces lymphocyte divisions, maintaining that importing transferrin receptors that are effective in lymphocyte divisions are reduced in the animals suffering from selenium deficiency; therefore, division capability of the lymphocytes drops and this is followed by a reduced immune response.

Peng et al. (2009) found that because of its difference in metabolic paths and more developed uptake processes, nano-selenium is more effective in lymphocyte cell division and specialization than other forms of this trace mineral. Studies have suggested that selenium improves immune response through increasing $T$ helper cells and improves secretion of cytokines (Burton et al., 1977). The improved immune response under nano-selenium treatment in this study was also confirmed by Funari Junior et al. (2012) and Payne and Southern (2005), who reported that because of its special surface region, large active surface centers, high catalytic efficiency, transfer capability, and higher surface uptake and stability, nano-selenium increases activities of cytokines and, therefore, leads to a better immune response compared with the other forms of selenium (organic and mineral) in poultry feeds. Increase in cytokines secretion occurs through influencing the mitogenic effects. Releasing cytokines results in a better nutrient uptake and cell growth and, subsequently, in production of immunogenic compounds (Grivennikov et al., 2010).

\section{Conclusions}

Although supplementing the feed with $1.2 \mathrm{mg}$ selenomethionine had a significant effect on weight growth and feed conversion ratio as compared with the control, the nano-selenium treatment improves feed intake, feed conversion ratio, and weight compared with the other treatments of the study. Besides, nano-selenium has a better performance in stimulating the immune systems of the broiler chickens in comparison with the other sources of selenium, since at nanoscales, selenium shows new and more powerful properties. Therefore, supplementing poultry feeds with nano-selenium is suggested to produce poultry with higher performance and improved immune system against diseases.

\section{References}

Abbas, A. K.; Lichtman, A. H. and Pillai, S. 2015. Cellular and molecular immunology. 8th ed. Elsevier, Philadelphia.

Ahmad, Z.; Sahota, A. W.; Akram, M.; Khalique, A.; Jatoi A. S.; Shafique, M.; Usman, M. and Khan, U. 2014. Pre and post-moult productive efficiency in four varieties of indigenous Aseel chicken during different production cycles. Journal of Animal and Plant Sciences 24:1276-1282.

Ahmadi, M.; Ahmadian, A. and Seidavi, A. R. 2018. Effect of different levels of nano-selenium on performance, blood parameters, immunity and carcass characteristics of broiler chickens. Poultry Science Journal 6:99-108.

AOAC - Association of Official Analytical Chemists. 2003. Official methods of analysis AOAC. 17th ed. Horwitz, W., ed. Arlington, VA.

Basmacıoğlu, H.; Ozkan, S.; Koçtürk, S.; Oktay, G. and Ergül, M. 2009. Dietary vitamin E ( $\alpha$-tocopheryl acetate) and organic selenium supplementation: Performance and antioxidant status of broilers fed n-3 PUFA-enriched feeds. South African Journal of Animal Science 39:274-285

Biswas, A.; Mohan, J. and Sastry, K. V. H. 2006. Effect of higher levels of dietary selenium on production performance and immune responses in growing Japanese quail. British Poultry Science 47:511-515.

Burton, R. M.; Higgins, P. J. and McConnell, K. P. 1977. Reaction of selenium with immunoglobin molecules. Biochimica et Biophysica Acta 493:323-331. https://doi.org/10.1016/0005-2795(77)90188-X

Cai, S. J.; Wu, C. X.; Gong, L. M.; Song, T.; Wu, H. and Zhang, L. Y. 2012. Effects of nano-selenium on performance, meat quality, immune function, oxidation resistance, and tissue selenium content in broilers. Poultry Science 91:2532-2539. https://doi.org/10.3382/ps.2012-02160

R. Bras. Zootec., 48:e20180256, 2019 
Canogullari, S.; Ayasan, T.; Baylan, M. and Copur, G. 2010. The effect of organic and inorganic selenium supplementation on egg production parameters and egg selenium content of laying Japanese quail. Journal of the Faculty of Veterinary Medicine, Kafkas University 16:743-749.

Cao, Y. Z.; Weaver, J. A.; Reddy, C. C. and Sordillo, L. M. 2002. Selenium deficiency alters the formation of eicosanoids and signal transduction in rat lymphocytes. Prostaglandins and Other Lipid Mediators 70:131-143. https://doi.org/10.1016/ S0090-6980(02)00018-7

Choct, M.; Naylor, A. J. and Reinke, N. 2004. Selenium supplementation affects broiler growth performance, meat yield and feather coverage. British Poultry Science 45:677-683. https://doi.org/10.1080/00071660400006495

Edens, F. W.; Carter, T. A.; Parkhurst, C. R. and Sefton, A. E. 2000. Effect of selenium source and litter type on broiler feathering. Journal of Applied Poultry Research 9:407-413. https://doi.org/10.1093/japr/9.3.407

Edens, F. W.; Parkhurst, C. R.; Havenstein, G. B. and Sefton, A. E. 2001. Housing and selenium influences on feathering on broilers. Journal of Applied Poultry Research 10:128-134. https://doi.org/10.1093/japr/10.2.128

Funari Junior, P.; Albuquerque, R.; Murarolli, V. D. A.; Raspantini, L. E. R.; Cardoso, A. L. S. P.; Tessari, E. N. C. and Alves, F. R. 2012. Diferentes fontes e níveis de selênio sobre a imunidade humoral de frangos de corte. Ciência Rural 42:154-159. https://doi.org/10.1590/S0103-84782011005000150

Grivennikov, S. I.; Greten, F. R. and Karin, M. 2010. Immunity, inflammation, and cancer. Cell 140:883-899. https://doi. org/10.1016/j.cell.2010.01.025

Hegazy, S. M. and Adachi, Y. 2000. Comparison of the effects of dietary selenium, zinc and selenium and zinc supplementation on growth and immune response between chick groups that were inoculated with Salmonella and aflatoxin or Salmonella. Poultry Science 79:331-335. https://doi.org/10.1093/ps/79.3.331

Invernizzi, G.; Agazzi, A.; Ferroni, M.; Rebucci, R.; Fanelli, A.; Baldi, A.; Dell'Orto, V. and Savoini, G. 2013. Effects of inclusion of selenium-enriched yeast in the diet of laying hens on performance, eggshell quality and selenium tissue deposition. Italian Journal of Animal Science 12:e1. https://doi.org/10.4081/ijas.2013.e1

Kojouri, G. A. and Sharifi, S. 2013. Preventing effects of nano-selenium particles on serum concentration of blood urea nitrogen, creatinine, and total protein during intense exercise in donkey. Journal of Equine Veterinary Science 33:597-600. https://doi.org/10.1016/j.jevs.2012.09.008

Kumar, N.; Garg, A. K.; Dass, R. S.; Chaturvedi, V. K.; Mudgal, V. and Varshney, V. P. 2009. Selenium supplementation influences growth performance, antioxidant status and immune response in lambs. Animal Feed Science and Technology 153:77-87. https://doi.org/10.1016/j.anifeedsci.2009.06.007

Liao, X.; Lu, L.; Li, S.; Liu, S.; Zhang, L.; Wang, G.; Li, A. and Luo, X. 2012. Effects of selenium source and level on growth performance, tissue selenium concentrations, antioxidation, and immune functions of heat-stressed broilers. Biological Trace Element Research 150:158-165. https://doi.org/10.1007/s12011-012-9517-3

Naylor, A. J.; Choct, M. and Jacques, K. A. 2000. Effects of selenium source and level on performance and meat quality in male broilers. Poultry Science 79:117-225.

Payne, R. L. and Southern, L. L. 2005. Comparison of inorganic and organic selenium sources for broilers. Poultry Science 84:898-902. https://doi.org/10.1093/ps/84.6.898

Peng, X.; Cui, Y.; Cui, W.; Deng, J. and Cui H. 2009. The decrease of relative weight, lesions, and apoptosis of bursa of Fabricius induced by excess dietary selenium in chickens. Biological Trace Element Research 131:33-42. https://doi. org/10.1007/s12011-009-8345-6

Perez, T. I.; Zuidhof, M. J.; Renema, R. A.; Curtis, J. M.; Ren, Y. and Betti, M. 2010. Effects of vitamin E and organic selenium on oxidative stability of $\omega$-3 enriched dark chicken meat during cooking. Journal of Food Science 75:25-34. https://doi. org/10.1111/j.1750-3841.2009.01478.x

Perić, L.; Milošević, N.; Žikić, D.; Kanački, Z.; Džinić, N.; Nollet, L. and Spring, P. 2009. Effect of selenium sources on performance and meat characteristics of broiler chickens. Journal of Applied Poultry Research 18:403-409. https://doi. org/10.3382/japr.2008-00017

Peterson, A. L.; Qureshi, M. A.; Ferket, P. R. and Fuller, J. C. 1999. Enhancement of cellular and humoral immunity in young broilers by the dietary supplementation of $\beta$-hydroxy- $\beta$-methylbutyrate. Immunopharmacology and Immunotoxicology 21:307-330. https://doi.org/10.3109/08923979909052765

Pighetti, G. M.; Eskew, M. L.; Reddy, C. C. and Sordillo, L. M. 1998. Selenium and vitamin E deficiency impair transferrin receptor internalization but not IL-2, IL-2 receptor, or transferrin receptor expression. Journal of Leukocyte Biology 63:131-137. https://doi.org/10.1002/jlb.63.1.131

Rama Rao, S. V.; Prakash, B.; Raju, M. V. L. N.; Panda, A. K.; Poonam, S. and Murthy O. K. 2013. Effect of supplementing organic selenium on performance, carcass traits, oxidative parameters and immune responses in commercial broiler chickens. Asian Australasian Journal of Animal Sciences 26:247-252. https://doi.org/10.5713/ajas.2012.12299

Ryu, Y. C.; Rhee, M. S.; Lee, K. M. and Kim, B. C. 2005. Effects of different levels of dietary supplemental selenium on performance, lipid oxidation, and color stability of broiler chicks. Poultry Science 84:809-815. https://doi.org/10.1093/ ps/84.5.809 
Sadeghian, S.; Kojouri, G. A. and Mohebi, A. 2012. Nanoparticles of selenium as species with stronger physiological effects in sheep in comparison with sodium selenite. Biological Trace Element Research 146:302-308. https://doi.org/10.1007/ s12011-011-9266-8

Shirsat, S.; Kadam, A.; Mane, R. S.; Jadhav, V. V.; Zate, M. K.; Naushad, M. and Kim, K. H. 2016. Protective role of biogenic selenium nanoparticles in immunological and oxidative stress generated by enrofloxacin in broiler chicken. Dalton Transactions 45:8845-8853. https://doi.org/10.1039/C6DT00120C

Spears, J. W.; Grimes, J.; Lloyd, K. and Ward, T. L. 2003. Efficacy of a novel organic selenium compound (zinc-lselenomethionine, Availa Se) in broiler chicks. p.197-198. In: Proceedings of the 1st Latin American Congress of Animal Nutrition, Cancun, Mexico.

Surai, P. F. 2002. Selenium in poultry nutrition: 2. Reproduction, egg and meat quality and practical applications. World's Poultry Science Journal 58:431-450. https://doi.org/10.1079/WPS20020032

Umesh, C.; Chaturvedi, C. and Richa, S. 2004. Viral infections and trace elements: A complex interaction. Current Science 87:11-18.

Wang, H.; Zhang, J. and Yu, H. Q. 2007. Elemental selenium at nano size possesses lower toxicity without compromising the fundamental effect on selenoenzymes: comparison with selenomethionine in mice. Free Radical Biology and Medicine 42:1524-1533. https://doi.org/10.1016/j.freeradbiomed.2007.02.013

Wen, W.; Weiss, S. L. and Sunde, R. A. 1998. UGA codon position affects the efficiency of selenocysteine incorporation into glutathione peroxidase-1. Chemistry and Biology 273:28533.

Yang, N.; Larsen, C. T.; Dunnington, T. E.; Geraert, P. A.; Picard, P. M. and Siegel, P. B. 2000. Immune competence of chicks from two lines divergently selected for antibody response to sheep red blood cells as affected by supplemental vitamin $\mathrm{E}$. Poultry Science 79:799-803. https://doi.org/10.1093/ps/79.6.799

Yoon, L.; Werner T. M. and Butler, J. M. 2007. Effect of source and concentration of selenium on growth performance and selenium retention in broiler chicken. Poultry Science 86:727-730. https://doi.org/10.1093/ps/86.4.727

Zhang, J.; Wang, X. and Xu, T. 2008. Elemental selenium at nano size (Nano-Se) as a potential chemopreventive agent with reduced risk of selenium toxicity: comparison with Se-methylselenocysteine in mice. Toxicological Sciences 101:22-31. https://doi.org/10.1093/toxsci/kfm221

Zhang, Z.; Liu, M.; Guan, Z.; Yang, J.; Liu, Z. and Xu, S. 2017. Disbalance of calcium regulation-related genes in broiler hearts induced by selenium deficiency. Avian Pathology 46:265-271. https://doi.org/10.1080/03079457.2016.1259528

Zhou, X. and Wang, Y. 2011. Influence of dietary nano elemental selenium on growth performance, tissue selenium distribution, meat quality, and glutathione peroxidase activity in Guangxi Yellow chicken. Poultry Science 90:680-686. https://doi.org/10.3382/ps.2010-00977 